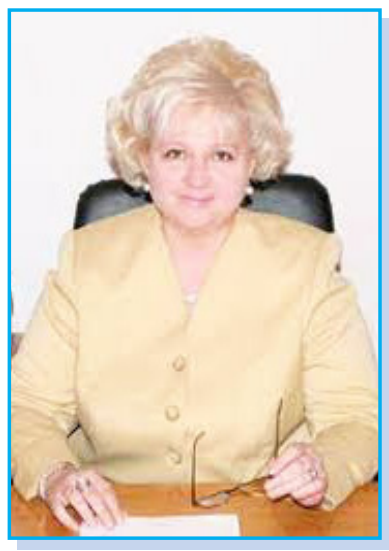

Людмила Калініна - доктор педагогічних наук, професор, сертифікований викладач Нідерландської школи в галузі Освітнього менеджменту (NSO - Nederlandse Schoolvoor Onderwijsmanagement), учений секретар Інституту педагогіки НАПН України, голова науково-методичної комісії з інформатизації закладів освіти НМР МОН України (з 2011 р.), науковий консультант Асоціації керівників шкіл України (з 1996 р.), Заслужений діяч науки і техніки України (2017 р.). Коло наукових інтересів: теорія та методика управління освітою, теорія активних складноорганізованих систем, реформування та модернізації системи управління в сфері освіти; інформаційний та стратегічний менеджмент. Автор і співавтор понад 300 наукових праць.

gelena@i.ua

http//orcid.org/ 0000-0003-0534-6089

https://doi.org/10.32405/2411-1317-2021-3-134-139

\title{
ПЕДАГОГІЧНА ЕКСПЕРТИЗА РОЗВИТКУ ЗАГАЛЬНОÏ СЕРЕДНЬОЇ ОСВІТИ РЕГІОНУ: ТЕОРЕТИЧНИЙ І ТЕХНОЛОГІЧНИЙ АСПЕКТИ
}

(відгук офіційного опонента, доктора педагогічних наук, професора Л. М. Калініної

на дисертацію Олени Миколаївни Касьянової, подану на здобуття наукового ступеня доктора педагогічних наук за спеціальністю 13.00.06 - теорія та методика управління освітою)

Актуальність теми дослідження не викликає жодних сумнівів, оскільки вона визначена комплексом проблем, які виникли в останні два десятиліття на теренах загальної середньої освіти (далі ЗСО) у зв’язку з трансформаціями в суспільстві та на національному ринку праці, що не лише загострили традиційні проблеми, а й створили нові, зумовлені, насамперед, зниженням якості освіти, неухильним падінням престижності вчительської праці, низьким рівнем її оплати, враховуючи один із найбільших у світі показників відносних суспільних витрат на освіту (7-7,5\% валового національного продукту), соціально-майновим розшаруванням населення країни.

У системі ЗСО, де стверджуються принципи демократичного врядування, виникли навчальні заклади приватної форми власності та конфесійної належності, налагоджують інформаційно-комунікаційні зв'язки та співпраця з інституціями громадянського суспільства й міжнародними організаціями, набуває поширення ідея переходу України до сервісної держави та взаємоузгодження державних, регіональних, місцевих і приватних інтересів у процесі надання/споживання загальної середньої освіти як державної управлінської послуги.

Упродовж останніх років країна втратила позиції у міжнародних рейтингах, зокрема за індексом глобальної конкурентоспроможності. Серед 133 країн світу Україна у 2010 р. посіла лише 89 місце, перемістившись із 69 місця порівняно з 2006 р. За даними Програми розвитку ООН, задоволені якістю національної системи освіти в Україні лише 38,0\% населення. Такий стан зумовлено відсутністю цілісної науково обгрунтованої програми розвитку сфери освіти загалом, та системи ЗСО зокрема, на засадах концепції сталого розвитку, управління інформаційними ресурсами, методологій системної динаміки й м'яких систем для досягнення оптимальних результатів на субрегіональному рівні щодо задоволення суспільних освітніх потреб. 
Відтак набуває актуальності розроблення та наукове обгрунтування теоретичних засад і технологій запровадження педагогічної експертизи, що забезпечує розвиток ЗСО регіону, оскільки технології та механізми, що в минулому забезпечували відносно стійкий стан ЗСО, за нових умов її функціонування, наведених вище, перешкоджають її поступальному розвитку. Варто також зазначити, що тематична спрямованість дисертації повною мірою узгоджується з основними положеннями державних актів і програм, зокрема: указами Президента України «Про Національну доктрину розвитку освіти» (2002р.), «Про заходи щодо забезпечення пріоритетного розвитку освіти в Україні» (2010р.), наказами МОН України № 553 від 24.07.2001 р.,№ 658 від 16.08.2004 р., № 847 від 24.12. 2003 р., № 1068 від 15. 09.2011р., № 847 від 24.12.2003 р. про порядок атестації ЗНЗ, затвердження ліцензійних умов надання освітніх послуг, проведення апробації та моніторингових досліджень якості навчальної літератури для 3Н3, регіональну експертну раду з питань ліцензування та атестації навчальних закладів (стор. 86-87 дисертації), прийняттям Національної стратегії розвитку освіти України на 2012-2021 рр., третім Всеукраїнським з’їздом працівників освіти 29 жовтня 2011 р. упродовж усіх років незалежності України.

Правильне виокремлення автором низки взаємоузгоджених соціально-педагогічних суперечностей на рівні управління ЗСО регіону та на рівні управління навчальним закладом дозволяє підтвердити актуальність та суспільну корисність дослідження.

Отже, дослідження О.М. Касьянової є своєчасним і перспективним, слугує науковим доробком до праць, присвячених експертній проблематиці в освіті.

Трансформації в контексті суспільних змін у країні, що відбуваються в останні десятиліття в соціально-економічній, техніко-технологічній і комунікаційно-інформаційній сферах, загалом ще не забезпечили помітний вплив на усталені концептуально-організаційні засади регіональних систем освіти. Наявність структурних, процесуальних, функціональних, мотиваційних, результативних змін у практиці ЗСО та відсутність інтегральних критеріїв розвитку освіти в контексті суспільних змін, системних досліджень, здатних створювати цілісні об’єктивні уявлення про стан функціонування й розвитку ЗСО в умовах модернізаційних змін, зростаючої активності суб'єктів системи освіти, спричинили необхідність запровадження не тільки прогресивних змін в освіті, а й розвиток педагогічної експертизи розвитку ЗСО регіону як державної управлінської та педагогічної послуги щодо надання рівних можливостей до якісної освіти та «...як певного сервісу щодо прийняття рішень у галузях суспільної практики».

Розроблення теорії і практики експертизи, визначення спрямованого становлення й розвитку регіональних освітніх систем, створення зразків експертної діяльності у сфері забезпечення якісної й доступної ЗСО учнівській молоді на засадах концепції сталого розвитку цивілізації, теорії адаптивного управління стали архіактуальними завданнями науки та освіти і $є$ новим пріоритетним напрямом наукових пошуків, які визначають не тільки прискорений науково-технологічний розвиток суспільства, а й його конкурентоспроможність у світі.

Актуальність проблематики дослідження зумовлена необхідністю впровадження експертизи та потребою показати роль педагогічної експертизи у розвитком ЗСО регіону, оскільки iї результати надають змогу суб’єктам НВП і управління поліпшити суть освітніх програм, модернізувати зміст освіти, якість навчального процесу та якість освіти, i, головне, сприяти розвитку здобувачів освіти. Експертне оцінювання може бути засобом втілення прогресивних освітніх ідей у практику через реалізацію оцінної та дослідницької діяльності розвитку ЗСО в системі громадсько-державного управління.

У площині сказаного виконана О.М. Касьяновою дисертаційна робота, безумовно, має наукову новизну, вагоме теоретичне і практичне значення для сфери освіти та репрезентує теоретичні та технологічні аспекти розвитку ЗСО як генетичної зміни якісних станів освітньої системи.

Важливо відзначити, що вперше розроблено й обгрунтовано теоретико-методологічні засади педагогічної експертизи, що репрезентують сутність, основні поняття, функції, систему 
принципів, форм і методів реалізації; обгрунтовано можливість використання концепції сталого розвитку в ЗСО регіону; розроблено модель педагогічної експертизи на засадах системного, діяльнісного, проектного, регіонального підходів і концептуальних основах теорії адаптивного управління та сталого розвитку цивілізації; розроблено й теоретично обгрунтовано технологію реалізації педагогічної експертизи в практиці управління загальною середньою освітою регіону; визначено й систематизовано комплекс організаційно-методичних умов, які впливають на ефективність педагогічної експертизи.

Практичне значення одержаних результатів полягає в тому, що вони можуть бути використані при здійсненні педагогічної експертизи в ЗСО регіону, розробці положення про соціальний інститут незалежних експертів. У Вступі подається загальна характеристика дисертації за всіма визначеними структурними елементами. Концепція дослідження як система поглядів на педагогічну експертизу представлено Оленою Миколаївною грунтовно через сукупність методологічного, теоретичного та технологічного концептів, систему доказових положень про експертизу, педагогічну експертизу та технологію їх реалізації. Однак, провідна ідея концепції дослідження виокремлюється окремим структурним елементом основної частини дисертації і не є складником концепції дослідження.

Вивчення та пізнання об'єкта наукового пошуку за допомогою різних видів аналізу (системний, генетичний, порівняльно-зіставний, креативно-прогностичний, ретроспективний, контент-аналіз) сприяли виробленню цілісного бачення досліджуваної проблеми оцінноекспертної діяльності в освіті, взаємозв’язку і взаємозумовленості її складових - концептуальних поглядів, теорій освітньої експертизи та кваліметрії, експертології, наукових підходів (онтологічний, що передбачає розкриття сутності експертизи як специфічного соціального феномена; гносеологічний, який зумовлює пізнання та філософське осмислення природи й сутності феномена експертизи; аксіологічний, що передбачає з'ясування природи та джерел ціннісних основ експертизи; телеологічний, який розкриває складну й суперечливу систему цілей як самої педагогічної експертизи, так і освіти взагалі; герменевтичний, що забезпечує розуміння й інтерпретацію використовуваних у процесі експертизи джерел, загальнометодологічних принципів експертизи та конкретно-методологічних принципів як принципів реалізації професійної діяльності експерта, форм і методів експертизи, що слугували розробленню й науковому обгрунтуванню теоретико-методичних засад педагогічної експертизи.

Свої наукові міркування під час розв’язання завдань дослідження дисертантка грунтує на міцному фундаменті нормативно-правових актів і методології оцінювання в освіті, теорії освітньої експертизи, сучасної освітньої парадигми, технології загальної організації мислення експерта, ідеях теорії системної миследіяльності, концепції сталого розвитку цивілізації, законах і принципах соціального управління, теорії адаптивного управління. Теоретична та методологічна основа дослідження проблеми пов'язана з ідеєю взаємозумовленості розвитку соціальної формації як суспільного явища, діалектичною теорією про загальний зв'язок, взаємозумовленість і цілісність явищ об’єктивної дійсності, теорією наукового пізнання, методологією системного аналізу, ідеями філософії освіти.

У дослідженні авторка вдало застосовує дескриптивний і ретроспективний аналіз становлення й розвитку експертизи у сфері освіти, термінологічний та контент-аналіз для з'ясування сутності та концептів базових категорій дослідження, зокрема, «експертиза», «процес експертизи», «атестаційна експертиза», «експертне оцінювання», «суб’єкт експертного оцінювання», «предмет експертного оцінювання», «експертиза в освіті», «педагогічна експертиза», «експертна діяльність», «експертна група», «групова експертна оцінка», «незалежна експертиза», «зовнішня експертиза», «внутрішня експертиза», «самоекспертиза», «функції експертизи», «теорія освітньої експертизи», «оцінювання», «дослідження для оцінки», «експертні оцінки», «експертні висновки», «експертні звіти», «експертні пропозиції», «експертні системи», «м'які експертні системи». Це дало змогу О.М. Касьяновій розробити й обгрунтувати теоретико-методологічні засади педагогічної експертизи (сутність, основні поняття, 
функції, система принципів, форм і методів реалізації) та успішно розв’язати перші чотири задачі дослідження.

У другому розділі різнобічно й грунтовно розкрито теоретичну основу (теорію глобальної стратегії, теорію адаптації та теорію управління за результатами) визначення та обгрунтування системи індикаторів сталого розвитку регіональної системи освіти, що структуровані у такі блоки, як соціум, освітнє середовище регіону, ресурси, інституційні характеристики; кваліметричні моделі для відстеження динаміки розвитку системи освіти регіону. На підставі взаємозв’язку характерних особливостей педагогічної експертизи й основних положень концепції сталого розвитку цивілізації, аргументовано доведено, що ефективна реалізація концепції сталого розвитку в ЗСО регіону можлива за умови впровадження педагогічної експертизи та доцільного використання експертами системи індикаторів, розробленої автором.

Широкий міждисциплінарний контекст досліджуваної проблеми дозволив дисертантці виокремити, обгрунтувати й покласти в основу побудови моделі педагогічної експертизи ЗСО регіону та технології її реалізації (третій розділ дисертації), соціально-філософські аспекти розвитку системи ЗСО, використати теорію систем, теоретичні основи адаптивного управління та синергетику як загальнонаукову методологію дослідження складних освітніх об’єктів, детально їх презентувати, конкретизувати загально методичні та специфічні принципи побудови моделі, розкрити сутність та специфіку педагогічної експертизи через процеси аналізу, оцінювання й прогнозування та діяльність суб'єктів педагогічної експертизи.

У четвертому розділі «Науково-методичне забезпечення педагогічної експертизи в загальній середній освіті регіону» висвітлено сукупність зовнішніх і внутрішніх факторів, що мають безпосередній вплив на запровадження й ефективний перебіг педагогічної експертизи; критерії ефективності педагогічної експертизи; розкрито основні якості, характеристики та вимоги до експерта в освіті, питання добору й оцінювання діяльності експертів, організації роботи експертних груп; алгоритм упровадження незалежної експертизи у практику ЗСО регіону; сформульовано методичні рекомендації педагогічним працівникам щодо організації й здійснення експертних досліджень і впровадження незалежної експертизи в загальну середню освіту регіону.

У п’ятому розділі «Експериментальна апробація моделі педагогічної експертизи розвитку загальної середньої освіти регіону» розкрито вихідні положення та методика проведення дослідно-експериментальної роботи, висвітлено результати експериментальної перевірки впливу запровадженої моделі педагогічної експертизи ЗСО регіону на якість управління освітою в регіоні, зростання професіоналізму педагогічних кадрів, якість освіти, що зумовлюють сталий розвиток загальної середньої освіти регіону.

Вважаємо, що експериментальна частина дисертації є ії своєрідною окрасою. Варто відзначити ретельне планування та сумлінне, навіть педантичне, виконання надзвичайно ємної і трудомісткої експериментальної роботи, чітку організацію і реалізацію всіх ії̈ етапів. У процесі дослідження одержано багатий фактологічний і експериментальний матеріал, який проаналізовано й узагальнено за розробленими індикаторами сталого розвитку регіональної системи освіти.

Дисертантом проведено досить грунтовний і розлогий триетапний експеримент, структурночасова організація якого видається логічною, доцільною і педагогічно виправданою. Експериментальна база дослідження свідчить про географічну широту, грунтовність проведеної експериментальної роботи та репрезентативність залученої до експерименту вибірки.

Разом із позитивною оцінкою щодо ходу і одержаних наукових результатів у дослідженні вважаємо за доцільне висловити окремі сумніви, зауваження загального плану та побажання.

1. Завдання дослідження досить повно й логічно розкривають послідовність реалізації поставленої мети, проте, деякі з них, потребують певної корекції. Зокрема, мета дослідження і завдання 5 практично ідентичні за сутністю і відрізняються лише первісним проце- 
сом проєктування моделі педагогічної експертизи, а процеси експериментальної апробації моделі та експериментальної перевірки моделі педагогічної експертизи є ідентичними за суттю, окрім апробованої, тобто «схваленої моделі», можливо експертами, а можливо - замовниками освітніх послуг.

2. Дисертація, особливо на початку, у другому та третьому підрозділах першого розділу, вміщує значну кількість авторських інтерпретацій джерел з проблематики дослідження, багато філософських роздумів (наприклад, с. 62-64) щодо природи та сутності феномену експертизи, може навіть переобтяжена такими роздумами та загальними положеннями щодо феномена дослідження. Це певною мірою ускладнює осмислення смислових зв’язків між базовими та похідними поняттями експертизи в педагогічній теорії, організацію практичної експертної діяльності щодо вивчення таких складних об’єктів як регіональних освітніх систем і процесів їх розвитку.

3. Концепція дослідження структурно утворена 3 трьох компонентів, одним 3 яких $є$ методологічний концепт, що включає фундаментальні філософські ідеї, філософські положення, діалектичну теорію та відображає взаємодію й взаємозв’язок різних наукових підходів загальнонаукової й конкретно наукової методології. Автором грунтовно репрезентовано сукупність наукових підходів у прескриптивній (нормативній) формі, тобто у вигляді прямих вказівок до експертної діяльності: пізнання, розуміння, визначення, розкриття, опис цієї діяльності у ракурсі процесу педагогічної експертизи, що наочно демонструє методологічне забезпечення дослідження та достатньо - високий рівень сформованості методологічної культури авторки дисертації. Однак, слід звернути увагу на те, що фундаментальні філософські ідеї, які входять до методологічного концепту, лише задекларовано О. М. Касьяновою без розкриття їх сутності. Натомість вони мали б сприяти реалізації провідної ідеї концепції, яка, на наш погляд, дещо багатослівна та «розмита» через задовге пояснення на чому вона грунтується, виникнення потреб та їх усвідомленні як на рівні державної політики, так і на регіональному або муніципальному рівнях.

4. У тексті дисертації трапляються термінологічні неточності, які ускладнюють розуміння сутності викладу основних положень дисертації. На сторінках дисертації автор використовує термін «розробка», наприклад, «...розробка його теоретичних засад англійським психологом...» (стор. 40), «Розробка та розвиток методу експертних оцінок...» (стор. 40), «...Він не зводить герменевтику до розробки методології розуміння текстів...» (стор. 68) й ін. та сторінках автореферату «...необхідність розробки відповідної моделі...» (стор. 3), «Теоретичний концепт передбачає розробку науково обгрунтованої моделі...» (стор. 7)». На нашу думку, варто застосовувати «розроблення», тобто дію з категорійним значенням «розробити, розробляти». Як відомо, у методології та наукознавстві загально прийнятою $€$ класифікація видів досліджень: фундаментальні, прикладні та розробки. Мають також місце невдалі чи незрозумілі фрази і словосполучення, як-то, «загальновживаною є думка...» (стор. 24), «Ми розділяємо інший погляд» (стор. 24), «...відмінною рисою експертизи» (стор. 36), «...через змішування понять «оцінювання» та «експертиза» виникає змішування завдань оцінки» (стор. 37), «..категоріальна» атестація» мала б бути «категорійна» (стосовно належності до категорії, розряду), (стор. 47) «поняттєво-категорійного апарату...» (стор. 8 автореферату) - «поняттєво-категоріального» - стосовно категорії, «теоретично обгрунтовано теоретико-методологічні засади педагогічної експертизи...) (стор. 8 автореферату), «праксометричні методи» (стор. 8 автореферату) та ін.

5. Стор. 2 автореферату: «Проблема управління середньою освітою на регіональному рівні $\epsilon$ актуальним напрямом наукових досліджень». На нашу думку, таке твердження не $\epsilon$ коректно сформульованим, оскільки проблема - це складне теоретичне або практичне питання, що потребує вирішення або розв’язання на регіональному рівні, але не представляє науковий напрям. 
6. Оскільки автор у дисертації розглядає м’які експертні системи (стор. 25), то на нашу думку, доцільно було б, окрім теорії системної миследіяльності Г. Щедровицького, реалізувати у дослідженні ще й системний аналіз у варіантах системної динаміки Дж. Форрестера та м’якої системної методології П. Чекланда, які б могли детермінувати методологічні основи проєктування моделі педагогічної експертизи у практиці управління ЗСО регіону та надали б змогу простежити взаємозв'язки в межах системи ЗСО, осягнути їх взаємозалежність та взаємовплив.

7. Автор на стор. 2 зазначає, що існує в педагогіці «...теорія освітньої експертизи». Дисертантці бажано б було розглянути або показати її взаємозв’язок з теоретикометодологічними засадами педагогічної експертизи, обгрунтованими в процесі дослідження.

Наведені у відгуку зауваження жодним чином не знижують загальної високої оцінки дисертаційної роботи О. М. Касьянової. Дисертація О. М. Касьянової написана на достатньому науково-теоретичному і методичному рівні, містить змістово багатий і ретельно розроблений автором новий теоретичний і практичний матеріал. А виявлені вади дослідження швидше свідчать про резерви фахового зростання науковця.

Всебічний аналіз виконаного шановною Оленою Миколаївною Касьяновою дисертаційного дослідження на рівні докторського узагальнення матеріалів, отриманих шляхом довготривалого експериментування, дав підставу в цілому оцінити його як фундаментальну працю, що має наукову новизну, теоретико-методологічне значення для загальної педагогіки, теорії і практики реформування освітньо-педагогічних систем, для подальшого запровадження педагогічної експертизи управління змінами, підготовки експертів для системи освіти, розвитку сфери освіти на підставі висновків незалежних і компетентних експертів.

Дисертантом уперше розроблено та впроваджено цілісну педагогічну теорію й технологію педагогічної експертизи, визначено й теоретично обгрунтовано комплекс організаційнопедагогічних умов, які впливають на ефективність педагогічної експертизи та сталість розвитку ЗСО регіону, побудовану на положеннях синергетики, діяльнісного, проєктного та регіонального підходів до реалізації принципу дитиноцентризму на субрегіональному рівні як суб’єкта гарантії якісного рівня освіти для кожної дитини.

Наукові здобутки автора з теми дисертації знайшли відображення в 1 одноосібній та 1 колективній монографіях, авторефераті, 24 одноосібних статтях у фахових наукових виданнях, 16 тезах у збірниках матеріалів наукових конференцій, 1 підручнику, написаному в співавторстві, у науково-методичних посібниках. Усього одноосібних публікацій - 47.

Результати дослідження впроваджено в практику управління освітою Жовтневого району м. Харкова (акт про впровадження № 1727 від 21.09.2010р.); відділу освіти Полтавської районної державної адміністрації (довідка № 01-28/2383 від 20.07.2011р.); управління освіти м. Охтирка Сумської області (довідка № 371 від 31.05.2010 р.), у навчальновиховний процес Сумського державного педагогічного університету імені А.С. Макаренка (акт впровадження результатів дослідження № 146 від 31.01.2012р.), Національного технічного університету «Харківський політехнічний інститут» (довідка про впровадження № 66-08-324/14 від 10.01.2012 р.).

На основі аналізу дисертації, автореферату та вивчення праць, опублікованих за проблематикою дослідження, відзначаємо надзвичайну актуальність здійсненого дослідження, обгрунтованість наукових положень, висновків і рекомендацій, сформульованих у дисертації, достовірність і новизну, повноту їх викладу в опублікованих працях, високий відсоток їх упровадження в широку освітню практику та робимо висновок, що дисертаційна робота «Педагогічна експертиза розвитку загальної середньої освіти регіону: теоретичний і технологічний аспекти», відповідає вимогам Порядку присудження наукових ступенів і присвоєння вченого звання старшого наукового співробітника затвердженого постановою Кабінету Міністрів України від 07.03.2007 № 423, а її автор, Олена Миколаївна Касьянова, заслуговує на присудження наукового ступеня доктора педагогічних наук зі спеціальності 13.00 .06 теорія та методика управління освітою. 